
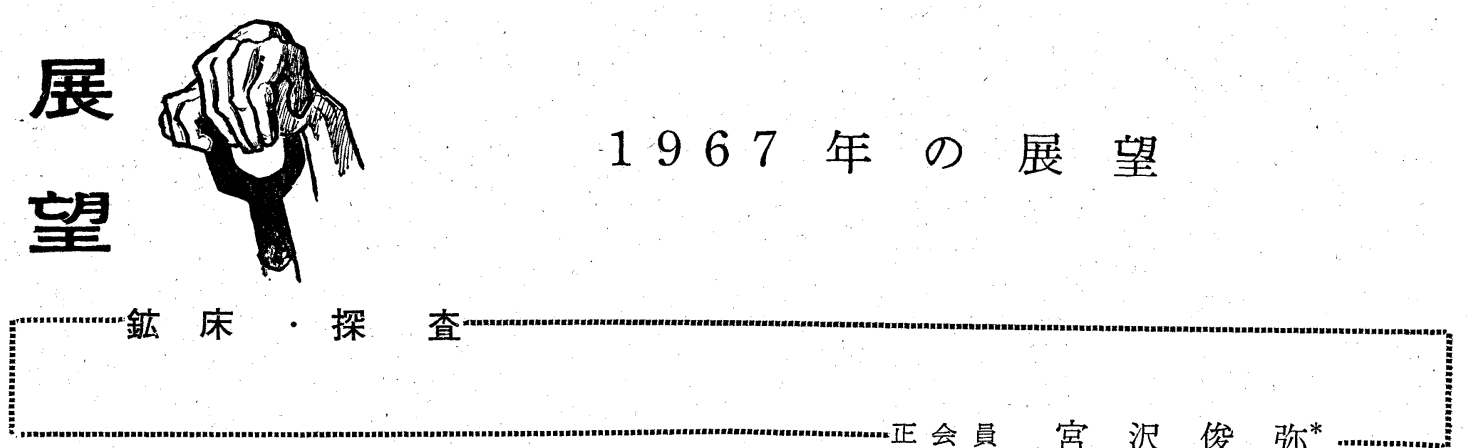

昭和 42 年度鉱床探査関係のトピックスを述べる。

\section{1. 国内}

\section{鉱 脈}

北海道䲨之舞鉱山の元山東部地域は，厚い流紋岩に覆 われており，その下部の探查はきわめて困難であつた。 しかしここと類似の地質構造を示す藤島地区において種 々の物探試験を行なつた結果，この種の地質構造に対し ては I. P. 法, 垂直探查法が有効であることがわかつて きた。本年度元山東部地域において，これらの方法を適 用した結果 2 カ所の異常地において試錐により金銀鉣床 の端緒を把握するに至つた。媣度はそれぞれ約 $100 \mathrm{~m}$ ， $250 \mathrm{~m}$ である。同じく轟鉱山では，昭和 39 年以降珠酸鉱 の生産とともに，地質調査を実施してきたが，同42年度 はかつての主脈であつた秀越銿・西大優越銿の取りあけ を行ない，同43年度からの本格的坑道ならびに試錐探鉱 の基礎づくりを行なつた。

秋田県阿仁鉣山では，昨年度開発した三之又地区に向 け，極印沢より稲荷坑立入を開さく，坑口より約 $900 \mathrm{~m}$ の地点で, 黒色頁岩中に 3 条の新鉣脈を捕捉し, 新たな 鈗源として開発中である。従来から粗粒玄武岩・花崗岩 以外では劣勢な鉱脈しかないと考えられ，また大部分が 露頭ないし旧坑下部のものを開発してきた。したがつて 今回黒色頁岩中け高品位の新鉱脈を捕捉した意義は大き い。山形県月山鉱山の探鉱は昭和38年以来休止していた が, 同 42 年 3 月から諸準備にかかり, 同 8 月坑道掘進に より探鉱作業を開始した。

北海道豊羽鉣山では, 主脈の $\mathrm{E}-\mathrm{W}$ 系播磨一但馬銿に 斜交する NW-SE 系の宗谷銿はいままでに銿押延長約 1,000m が確認されていたが，その後坑内試錐によつて 延長の伸展が予想され, 総延長 $2,000 \mathrm{~m}$ が推定されるに

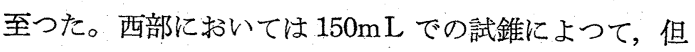
馬銿の下盤に大江沢 1 号および 2 号銿を把握した。大江 沢 2 号銿は平均幅 $360 \mathrm{~cm}$, 品位 $\mathrm{Pb}+\mathrm{Zn} 15 \%$ で, 延長は $600 \mathrm{~m}$ が推定されているが，両銿先はなお優勢に発展す るもののようである。さらに但馬銿の上盤の新備前銿お よび備前銿では，これらの脈の西方銿先を把握した。東

* 本会地質釷床及探査専門委員長, 理博 東京教育大学教授 理学部 地鉣教室
部においても播磨銿の下盤で，通洞系の下盤脈に逢着 し，この方面の発展にも十分の期待がもてるに至つた。 新潟県南越鉱山では, 日向鉱床等の開発が進展して, 鉱 脈の性状がようやく明らかとなつてきた。鉱脈は，走向 $\mathrm{N} 70^{\circ} \mathrm{E}$, 傾斜北方で, シュートはNW方向 $45^{\circ}$ 程度で, 雁行構造を呈しているようである。また昨年に引続きあ らやま地区の精査を行なつた。長崎県対州鉣山の鉣脈裂 カパターンは, $\mathrm{N}-\mathrm{S}$ 系正断層, $\mathrm{N} 30^{\circ} \mathrm{E}$ 系層面系逆断層 を主としているが，本年の前半は特に構造の解明につい て再検討を行ない，日見鉣床の上盤に新鉣床を発見し， 10 号下盤層面銿・20号上盤層面銿・裏河内層面銿等の発 展をみることができた。本鉱山の鉱脈には，一般に上部 より下部に向つて, 鉛・覀鉛・磁硫鉄鉱の帯状分布が知 られているが, 最近深部において随所に鉛・亜鉛鉣が発 見され，鉱化作用に繰返しのあることがほぼ明らかにな つてきた。

稲倉石鉱山では, 構造規制の面から, 万盛鉱床の南 $700 \mathrm{~m}$ に並行脈として存在する奥稲倉石鉣床の発展がま たれていたが，昭和 41 年より開発を再開中の亡ころ，本 年 2 坑道 (海抜 $+150 \mathrm{~m}$ ) 上部で富鈗体 (朝日脈西第 1 富 鉱体）に逢着し，目下探鉱坑道を展開中である。若干の マンガン方解石を含むが，規模の上では万盛鉱床に匹敵 するものと予想されるので，つぎの鉱体を目指し，さら に西部開発のため坑道掘進を促進する計画である。さら に本鉣山の主脈と目される前記万盛鉱床通洞脈について は, 従来東方に向つて開発を展開してきたが, ほぼ目的 を達成したので，これからの開発目標を西部地域に指向 し, 試錐の結果鉱徴をつかみ, 昭和 42 年坑道掘進を開始 した。この結果現在まで 8 坑道（海抜一 $30 \mathrm{~m}$ ) において 延長 $110 \mathrm{~m}$ の高品位釷体（万盛鉱床西第 1 富鉱体）に着 鉱, 目下さらに探鉱継続中である。

\section{黒鉱鉱床}

北海道国富鉣山では，前年度試錐により鉣徵を把握し た辰五郎沢において, 試錐をさらに強力に推進した結 果, 鉱床胚胎層準が北西に発展することが判明した。す でに確認された規模は, 長径約 $400 \mathrm{~m}$, 短径約 $130 \mathrm{~m}$, 層 厚約 $9 \mathrm{~m}$ (最大 $15 \mathrm{~m}$ ) である。鉣層はこの範囲内に 2 層 ないし 3 層になつて存在し, 品位は $\mathrm{Cu} 0.7 \%, \mathrm{~Pb}+\mathrm{Zn}$ 
$10 \%$ 前後である。年末近くさらにこの東北方約 $100 \mathrm{~m} の$ 旧富田坑付近に拉いて 2 層の鉱床を把握し，目下その広 がりを追跡中である。秋田県小坂上向鉱床では，昭和 41 年以来継続してきた鉱量確認のための試錐を一応終了 し，新たに立坑開さくを開始し，その開発に着手した。 さらに鉱床の南方銿先延長に対し, 試錐探鉱を実施中で ある。秋田県釈迦内鉱山では，前年度までに発見した第 8 鉱体に続いて，本年度は第9・10・11の3 鉱体を試錐探 鉣によつて発見した。なかんずくNo.450試錐孔で把握 した第11鉱体は深度約 $300 \mathrm{~m}$ で, 厚さ $11 \mathrm{~m}$, 平均品位 $\mathrm{Cu}$ $7.5 \%, \mathrm{~Pb} 4 \%, \mathrm{Zn} 24 \%$ のきわめて優秀なものであつ た。花輪鉱山では試錐探鉱によつて本山鉱床下部に新鉱 体を発見し，明通鉣床の発展とともにさらに希望が大き くなつた。福島県田代鉱山の大塩鉱床は試錐ならびに坑 道探鉱によつて大略の鉱画・鉱質が判明したので，昭和 45 年度から月産 $10,000 \mathrm{t}$ 計画で操業に入るべく準備中で ある。島根県鰐淵鉱山では，付近一帯が広域調査北島根 地区に指定され，地質調查・構造試錐が行なわれたが， 鉱山自身でも坑外試錐機 2 台を常時稼働させ，鉱床探査 を積極的に行なつている。

\section{キースラーガー}

愛媛県別子鉱山筏津鉱床と佐々連鈗山金砂銿は，地表 調查の結果，おのおの延長方向に興味深い示徵が得られ た。現在これらについて検討中であるが，その結果銿先 延長の探査に対する重要な指針が与えられそらである。

\section{ウラン鉱床}

従来国内ウラン資源の深査にあたつてきた原子燃料枀 社探釷開発部は昭和 42 年 10 月 2 日改組され, 動力炉・核 燃料開発事業団探釷開発部々なつた。本年度は既知鉱床 に対する探査と並行して, 新鉱床発見のためのカーボー ン探査を重点的に実施した結果, 山口県荻市東方, 同県 豊浦郡豊田町, 長野県飯田市千代地区, 福島県いわき市 小川町の 4 s所で，顕著な放射能異常を発見した。その 後の地質調査により，豊田町以外のものは，いずれも花 崗岩を基盤とした第 3 紀層中のもので，今後大規模な鉱 床に発展する可能性の大きなものであることが明らかと なつた。豊田町の異常は中生代白亜紀の関門層群基底部 の礫岩中におけるもので，鉱床はまだ発見（昭和 42 年 12 月）より日が浅く，詳細は不明であるが，昭和 41 年 11 月 高品位露頭 (品位 $0.7 \% \mathrm{U}_{3} \mathrm{O}_{8}$ ) 加発見され, 現在試錐に よつて鉱床の連続を追跡している山口県油谷湾地区にお けるものと類似のものと考えられるので, 今後の発展が 期待される。既知鉱床の探査は岐㚖・愛知両県にまたが る東濃地区で重点的に行なわれ,この結果瑞浪市月吉, 可 児郡御蔓町謡坂, 同町美佐野の 3 鉱床において, 鉱量が 計 $4,366,000 \mathrm{t}$ （品位 $0.056 \% \mathrm{U}_{3} \mathrm{O}_{8}$, 含有ウラン量 2,440 t）に達した。また, 東濃地域周辺の瀬戸市内等で新鉱
床の発見が相ついでおり，この方面の探查の結果が期待 される。

\section{石炭鉱床}

長崎県松島炭鉱では北部海底の原料炭開発のために, 大島鉣区の海上孤島の蟹瀬に $1,700 \mathrm{~m}$ の通産省委託の試 錐工事を，昭和 41 年 5 月 7 日より開始し，同 42 年 3 月 29 日に完了した。同西彼杵郡外海町沖合の古河鉱業外海鉣 区は, 高島炭田と崎戸・松島炭田との中間にあたり,従来 加ら地質学的にも, 石炭資源開発の上からも注目されて いた地域であり，国内原料炭の長期安定供給体制の確保 の政策に沿つて，開発のための基礎調查が鋭意進められ てきた。すなわち，昭和 34 年重力探查 (地質調查所), 同38 39年周辺島嶼に招ける試錐 (石炭局・松島炭鉱), 同39年音波探査(古河鉱業)，同41年地震探査 (石炭局・ 松島炭鉱・住友石炭鉱業・古河釷業・三菱鉱業) などが 行なわれてきた。昭和 42 年 9 月より，これらの結果に基 いて鉱区内において“第1 探海号”による海上試錐を実施 し，石炭鉱床を把握した。本試錐調查は同 42 年12月現在 なお実施中であるが，きわめて意義の深いものであり， さらに今後の調查の結果が期待される。

\section{2. 海 外}

\section{使節団の派遣}

銅・鉛・亜鉛等を中心とする非鉄金属鉱物の今後の需 要増に対処するため，海外における鉱物資源のわが国の 自らの手による探鉣開発の必要性が強く叫ばれている が，通産省としてもこの際海外諸国の政府および業界と の充分なる意見の交換を行ならことにより，将来の探鉱 開発を効率的に行ないらるよう本年度は 2 回にわたり鉱 業使節団を派遣した。第 1 班は河上住友金属鉱山社長を 団長とする団員11名, 随員 2 名で構成され，3 月29日東 京を出発し, 約20日間にわたり, フィリピン・オースト ラリア両国を訪問した。この間相手国政府ならびに業界 に対して，わが国非鉄金属の需給の見通しならびに原料 輸入の必要性を説明し, 開発協力関係の強化が両国経済 発展のため，双方に利益の多いことを披歴し，具体的問 題として(1)基礎的調査段階からの開発参与方式の可能性 の打診，(2投資ならびに技術者・労働者の受入れ活動の 問題点等について意見の交換を行なつた。この結果両国 とも基本的にわが国の考え方に対する理解を深め，かつ 今後発生するであるら諸問題の解決のための有力な意見 調整がなされる等, 多大の成果をあげた。第 2 班は山県 三菱金属鉱業会長を団長として，団員 10 名，随員 2 名で 構成され，10月11日東京を出発し，約20日間にわたり， 南米のチリー・ペルー・ボリビヤ 3 カ国を訪問した。本 班も第 1 班同様の成果をあげたが，特にチリーにおいて は日本・チリー合併の探鉱会社設立の基本構想が打出さ れる等より具体的な成果もあつた。 


\section{ウラン鉱業事情調査団の派遣}

原子力発電の発展に伴い，わが国が今後必要とする天 然ウラン量は膨大なものになると予想されているが，わ が国のウラン資源はきわめてそしく所要量の大部分は海 外に依存せざるを得ない状況にある。将来のウラン需要 のすべてを，単純輸入により賄うことは，安定性および 低廉性の面で問題があり，海外探鉱開発により，所要量 の相当程度を確保する必要があると考えられるが，わが 国企業の海外進出の機運はまだ熟していない。一方カナ ダ・アメリカ合衆国は世界有数の資源国であり，かつ両 国のウラン鉱業は産業としての古い歴史を有し, さらに 発展しようとしている。通産省としでもウラン資源確保 対策，特にウラン鉱業育成策を確立する必要があると考 えており，カナダ・アメリカ合衆国におけるウラン鉱業 事情を調查し， ウラン鉱業を支える環境条件をさぐると ともに，長期需要見通し，わが国進出の可能性を調查す るため, 日本原子力産業会議に調査を委託し，非鉄金属 業界を中心とする調查団を派遣した。調查団は同和鉱業 高木開発部長を団長とし，10月31日東京を出発, 約 1 力 月にわたり，カナダ・アメリカ合衆国の関係政府機関， ウラン鉱業会社および鉱山現場を訪問，調查を行ない， 多大の成果をあげた。なおこれより先，1月に当時の原 子然料公社の神山理事がオーストラリアで基礎的な事情 調查を行ない，また 3 月下旬，日本鉱業・同和鉣業・古 河釷業・住友金属鉱山・开金属鉱業・日本釷業協会・ 原子然料公社からの 9 名からなるウラン資源調查団がカ ナダに派遣され，同国オンタリオ州エリオット・レーク 地域の鉙床の共同探鈗開発の可能性について予備的な話 合いが行なわれた。

\section{海外探鉱事業費補助金に上る調査探鉱。}

将来の非鉄金属鉱物の需要増に対処するための海外探 鈗開発の重要性に鑑夕，政府の援助策の一環として，昭 和 41 年度から海外鉣物資源開発に補助金を交付して有望 プロジェクトの探鉱の助成を行なつている。本年度は昭 和41年度に引きつゔきチリー・アンデスの Copper belt の広域的調査と資料情報の収集を行なつた。この地域に ついては，同41年度にサンチャゴ・アントファガスタ間 の南北約 $1,250 \mathrm{~km}$, 幅約 $80 \mathrm{~km}$, 面積 $100,000 \mathrm{~km}^{2}$ にわ たつて航空調查を行㣻い，写真地質学等を駆使して 251 の変質帯を抽出した。本年度はこれらのらち有望なもの 205について,海外鈗発小川団長を中心とする調查団が 9 月 8 日から約 3 月䦕にわたつて地質調查を行なつた。 なお資料情報の収集はすべての海外探鉱開発の基礎とな るものであり, 本年度も41年度に引きつつきき精力的に行 なつた。

\section{鉱山開発}

カナダの Brenda 鉱山では探脏作業, $F / R$ 検討作業
が終了，開発準備作業が開始された。同じくブリィテ イッシュ・コロンビア州のハイランド・バレーにある Highmont 鉱山では試錐探查を終了, 現在坑道探鉱と バルクサンプリング作業が鋭意進められている。ペルー の Condestable 鉱山ではさらに鉱量が広大し, 増産計 画が検討されており，同じくChapi 鉱山でも開発準備 が着々と進められ，明年度より本格的な選鉱場建設作業 が開始される予定である。フィリピンでは長年の懸案で あつた Marcopper 鉱山の開発が，会社法・外資奨励 法等の改正に伴い，ようやく実施の見通しが得られるに いたり，明年度より本格的開発作業が開始される見込み となつた。アフリカ・コンゴ・カタンガ州の Copper belt に対し日本鉱業が独占的探鉱権を獲得し，同社は現 在広域調査・試錐探鉱を実施中である。

\section{3. 物 理 探 鉱}

I.P. 法が国内のみならず，ペルー(日本鉱業)・カナ ダ (住友金属鉱山) など海外の調查でも活用されるよう になつた。またI.P.送信機の国産化が進められ，外国製 品と同等以上のものが作製されるようになつた。北海道 鴻之舞鉱山では厚い流紋岩に覆われた地域の下部探査に 本法が有効であることが判明した。愛媛県別子・佐々連 両鉱山では，数年前に実施した試験研究の結果から，既 知鉱床の銿先延長部の探査に対しては流電電位法が効果 的であることがわかり，昭和 41 年度から応用調查を行な つている。本年度からは地表調査に加え, 試錐孔を利用 した調查も行ない，鉱床層準決定のための資料を得るこ とにつとめている。一方探鉱事業団が実施した S-4 と S-5の試錐孔を利用した検層の結果においても，鉱床層 準の決定および鉱床の位置の推定に対する有効なデータ が得られている。これらは深度1,000 1,500m前後に存 在する鉱床を問題としている点で画期的なものであり， 今後さらに本法の発展確立が望まれる。

\section{4. 試錐}

北海道豊羽鉱山では，坑内探鈗をワイヤーライン工法 で実施し，水平試錐としてはわが国で初めての深尺 930 $\mathrm{m}$ を完遂した。この工法の特徵を記述するとつぎのよう である。1.オーバーショットの改良, 深尺となるとコ ア採取に際し，インナーチューブおよびオーバーショッ 卜を出し入れする時間が長くなる。これを短縮するた め，オーバーショットに水路のバイパス装置を考案し， 摩擦抵抗を小さくして使用し，効果を発揮した。2. 才 一バーサイズと標準サイズとワイヤーラインビットのコ ンビネーション使用により，ノンケーシング錐進を行な い，ポンプ圧の上昇を防いだ。3．ロッド潤滑剤の使用 4. 適正なビット回転数を得るため試錐機のメーンプー リーの変換使用, 以上により従来のワイヤーライ以試錐 にくらべて，掘進工程約 $33 \%$ の昇が得られたほか心 合 
後の深尺の水平試錐における指針となる工法を確立する ことができた。三重県紀州鉣山では，昭和39年より，試 錐にワイヤーライン工法を採用しはじめ, 同42年上期使 用中の大型・中型機 9 台に対しすべてこの工法を取入れ た。これにより一工あたりの作業量が約 2.5 倍となり， 探鉱の成果が上つた。岡山県柵原鉱山では，先に EXサ イズのダイヤモンド・ビットの薄肉化を計り, 実用化し たが，これをワイヤーライン・ビットにも適用するた め, 昭和 41 年下期 AXサイズについて試験研究を行な い, ビット外径は同じで, 内径を $29.2 \mathrm{~mm}$ とした薄肉化 (AX-YWL) に成功した。その結果, 従来の “10” シリ 一ス・ビットと比較して, ドリリング・スピード $143 \%$, コア一詰 1 回当り穿孔長 $139 \% ， 1$ 方当り掘進長 $127 \%$, ビットリセット費/ $\mathrm{m} 67 \%$ となつた。さらに BXWLに ついても YWL として同様の成績をあげている。この ビットの薄肉化と相まつて, 潤滑油の利用（掘さく水に 添加）は，特に硬岩掘進に著しい成果をあげることがで きた。岩手県赤金鉱山では, 坑内空動試錐機の口径の小 型化を研究し, $38.1 \mathrm{~mm} \phi$ のものを $29 \mathrm{~mm} \phi$ にすること によつて，掘進速度を 2 倍にすることに成功した。なお 前記第 1 探海号 (太平洋探海工業) は, わが国最初の本 格的な外洋型の海上試錐船で，昭和 40 年以来北海道釧路 沖において, 海底炭田の調査に従事してきたものであ り, 今後も大陸棚の資源調查船として, その活躍が期待 されている。第 1 探海号は総 $\mathrm{t}$ 数 $500 \mathrm{GT}$ で, 性能は掘 さく機 N-1000型ドローウォークス, 櫓位置 中心井式 (径 $3 \mathrm{~m}$ ), 櫓高 $20.60 \mathrm{~m}$ (ジャックナイフマスト), 掘さ 〈深度 $4 \frac{1}{2} 2^{\prime \prime} 1,000 \mathrm{~m}, 3 \frac{1}{2} 2^{\prime \prime} 1,500 \mathrm{~m}$ 作業可能水深 200 $\mathrm{m}$ (現在までの実績 $60 \mathrm{~m}$ ), 錨泊ダンフォース型アンカ 一にて 8 点錯泊，掘さく方式ワイヤーラインコアリング 法である。

\section{5. 広域調查・精密調查}

広域調查の昭和 42 年度の調查地域は同 41 年度と同じく 11地域であるが，その事業規模は同 41 年度の 150 百万円 から 280 百万円へと飛躍的に増大している。これは物理 探査・試錐本数の増加によるもので，物理探查について は新たに地震探査も取り入れられ，いよいよ本格的な調 查実施の段階に入つた。なお同41年度に紀の川・白髯山 両地域の広域調査が終了し，同42年度には新たに国富・ 下北両地域が広域調査区域に追加された。

精密調查は, 昭和 42 年度において新たに紀の川地域を 加え, 従来の北鹿・白髮山両地域と合せて 3 地域につい て実施されているが；その事業規模も約 267 百万円と逐 年増加して充実した調查が行なわれている。なお本年度 をもつて北鹿地域の精密調查は完了することになる。

これら広域調查・精密調查によつて従来必らずしも充 分ではなかつた地質構造の解明・層序の確立等が行なわ
れ，また鉱床胚胎の可能性についての調査が進み，この 結果, 従来あまり効率的に行なわれていなかつた企業探 鉱に大きな指針を与え, 効率的な企業探鉱が実施されつ つあり, 広域調査一精密調查一企業探鉱のいわゆる 3 段 階方式の成果をあげつつある。

\section{6. 研 究 分 野}

本会地質鉣床及探査専門委員会では，昭和 42 年度春季 大会 (東京)に㧍いて，「坑内水」と「地熱エネルギー 資源」に関する研究会を行なつた。前者ではおもに水質 ・出水機構などについて 7 講演が, 後者では世界各地の 地熱の探査開発について 8 講演が行なわれ，いずれも興 味深い研究・調查の結果が発表され, 活発な討論が行な われた。日本鉱山地質学会ほか 4 学協会との共催による 秋季大会 (福岡) では「含金珪酸鉱」・「海外に括ける 物理探査技術」・「海上物理探査技術」・「最近の物理探 查技術の進歩」・炭鉱廃石の利用」の 4 研究会が行なお れ, 多数の貴重な研究・調査の成果が発表された。4月 6 日黒鉣選鉱特別研究委員会と合同で第 2 回目の黒鉱に 関する座談会が開かれ，特に鉱物組成と組織，鉱物の酸 化性などにテーマをしぼつて活発な討議が行なわれ，実 り豊かな成果があげられた。また現地研究会が 2 月長崎 県の高島炭鉱と対州鉱山で開催され，現場見学後有意義 な討論会が行なわれた。9月 8 日〜17日スコットランド のセント・アンドリウスにおいて第 2 回国際鉱床学連合 の会議が開催され，28カ国から約 110 名の出席者があつ た。日本加ら注東大渡辺武男，東北大竹内常彦，東京教 育大宮沢俊弥の 3 名が代表として出席したほか，山口大 亘木浅彦，地質調查所佐々木昭が参加した。おもに鉛・ 亜鉛鉱床の成因, 鉱流動体の起源, 鉱床生成の深度と下 限，母岩の変質などについての講演がなされ，活発な討 論が行なわれた。また液体包有物の研究の重要性が改め て認識された。

鉱床学の各分野における記載的研究は今年も数多く発 表されたが，特に日本では従来ほとんど行なわれなかつ た鉱石鉣物の反射能や硬度の精密な測定がなされるよ5 になつた。一方理論的・実験的研究はますます活発とな り，多数の論文が国の内外で発表された。特に鈗物の合 成に関する研究, 濃度の高い水溶液中における鉱物の溶 解度に関する研究などが盛んとなり，また鉱床の成因や 鉱液の起源を明らかにするため単一の液体包有物につい て放射化分析が試みられるよ5な機運になつてきた。本 年も寸ぐれた鉱床関係の研究書・参考書がいくつか出版 されたが，特にほとんど同時に出版された Researches in Geochemistry Vol. 2 (Abelson 編) とGeochemistry of Hydrothermal Ore Deposits (Barnes 編) 任 好著である。 